\title{
Peranan Orang Tua Dalam Masa Perkembangan Pubertas Anak di SMP Negeri 4 Kota Bima Tahun Pelajaran 2018-2019
}

\author{
Nur Syariful Amin, Amiruddin \\ STKIP Bima \\ e-mail : amin.stkipbima@gmail.com, amiruddin7251@gmail.com
}

\begin{abstract}
Abstrak
Peranan orang tua mendidik anak dalam rumah tangga, sangatlah penting artinya, karena dalam rumah tanggalah seorang anak mula-mula memperoleh bimbingan dan pendidikan dari orang tuanya. Tugas ibu dan bapak adalah sebagai guru atau pendidik utama dan pertama bagi anak-anaknya dalam menumbuhkan dan mengembangkan kekuatan mental, fisik dan rohani mereka. Bagi orang tua yang sadar mengenai pentingnya pendidikan anak usia sekolah di dalam rumah tangga, akan memandang anak itu sebagai makhluk yang berakal yang sedang tumbuh, bergairah, dan ingin menyelidiki segala sesuatu yang ada disekitarnya. Maka tujuan penelitian ini adalah ingin mengetahui peranan orang tua dalam masa perkembangan pubertas anak di SMP Negeri 4 Kota Bima Tahun Pelajaran 2018-2019. Yang menjadi subjek penelitian ini adalah 20 orang tua/wali siswa yang memiliki peranan dalam perkembangan pubertas anak pada SMP Negeri 4 Kota Bima. Untuk mengetahui gambaran peranan orang tua tersebut, maka peneliti memberikan angket kepada seluruh siswa yang merupakan anak dari orang tua siswa dalam penelitian. Berdasarkan hasil angket tentang peranan orang tua anak usia pubertas pada SMP Negeri 4 kota Bima berdasarkan hasil pernyataan siswa atau anak usia pubertas, sering memenuhi kebutuhan, memberi kasih sayang dan merencanakan karir anak, sehingga tanggung jawab dalam perkembangan psikis mendapat presentase $87.87 \%$ merangsang intelektual anak untuk terus belajar, menanamkan akidah tauhid sehingga kemampuan orang tua mendidik dan membimbing anak pubertas mendapat persentase 84,64\% dan memberikan seperangkat nilai dan sistem etika sehingga tanggung jawab dalam perkembangan psikis mendapat persentase 88,98 $\%$ hal ini oleh hasil persentase dan terletak antara $80 \%$ - $90 \%$, sehingga disimpulkan bahwa peranan orang tua dalam masa perkembangan pubertas anak pada SMP Negeri 4 Kota Bima Tahun Pelajaran 2018-2019 termasuk kedalam kategori "baik". Hasil penelitian ini dapat dismpulkan bahwa peranan orang tua yang selalu melaksanakan tanggung jawabnya, memberikan kasih sayang, mendidik dan membimbing dengan baik, akan sangat membantu perkembangan pubertas anak, pada akhirnya tugas perkembangan anak pada masa yang dianggap sulit ini bisa dipenuhi dengan baik dan bisa untuk menghadapi dan melaksanakan tugas-tugas perkembangkan selanjutnya. Hal ini dibutuhkan kerja sama dari oranag tua, guru dn lingkungan masyarakat luas untuk menyiapkan kondisi yang kondusif bagi perkembangan anak secara sehat. Sehingga permasalahan dapat diatasi pada akhirnya prestasi belajar anak dapat diraih semaksimal mungkin.
\end{abstract}

Kata kunci: Peran, Orang tua, Pubertas 


\section{PENDAHULUAN}

Peranan orang tua mendidik anak dalam rumah tangga, sangatlah penting artinya, karena dalam rumah tanggalah seorang anak mula-mula memperoleh bimbingan dan pendidikan dari orang tuanya. Tugas ibu dan bapak adalah sebagai guru atau pendidik utama dan pertama bagi anak-anaknya dalam menumbuhkan dan mengembangkan kekuatan mental, fisik dan rohani mereka. Bagi orang tua yang sadar mengenai pentingnya pendidikan anak usia sekolah di dalam rumah tangga, akan memandang anak itu sebagai makhluk yang berakal yang sedang tumbuh, bergairah, dan ingin menyelidiki segala sesuatu yang ada disekitarnya. Itu pula mengapa orang tua perlu merasa terpanggil untuk mendidik anak-anaknya sejak kecil, demi mengembangkan segala potensi yang masih terpendam dalam diri mereka (Henry N, 1991).

Kenyataan menunjukkan bahwa banyak orang tua yang lalai, lupa dan belum memahami cara melaksanakan tugas mendidik yang mulia ini. Anggapan yang lazim terjadi adalah orang tua mengatakan bahwa kalau anak sudah masuk di sekolah atau sudah diserahkan kepada guru di sekolah, maka selesailah tugas mereka dalam mendidik anak, apalagi sudah masuk usia pubertas. Tugas orang tua bagi mereka hanyalah mencari uang untuk membiyai sekolah anak-anak mereka. Kondisi ini akan lebih parah lagi jika orang tua terus beranggapan seperti ini bila anak-anak mereka telah menginjak usia pubertas. Karena masa pubertas ini bagi anak adalah masa yang rentan dengan masalah dan sangat membutuhkan perhatian yang serius dari orang tua dan pendidik lainnya.

Berdasarkan pengamatan awal yang dilakukan pada siswa usia pubertas (12 - 18 tahun) di Sekolah Menengah Pertama (SMP) 4 Kota Bima, didapatkan sejumlah pernyataan siswa tentang peranan orang tuanya dalam membimbing mereka. Dari sebagian responden atau siswa mengatakan bahwa orang tua mereka enggan memberikan bimbingan yang telaten dan mendengarkan pendapat mereka. Sebagian siswa tidak mengetahui tugas-tugas perkembangan yang harus mereka penuhi dan jarang orang tua memberikan penjelasan tentang tugas-tugas tersebut. Akibatnya banyak siswa yang menunjukkan perilaku yang menyimpang dalam bentuk melanggar tata tertib sekolah dan memiliki prestasi belajar yang rendah dan mengarahkan pada tindakan kenakalan anak (Juvenile deliquency).

Mengingat besarnya manfaat peranan orang tua bagi anak-anak sekolah khusus masa pubertas dalam membimbing dan mendidik mereka sebagai generasi penerus harapan bangsa, maka peneliti sangat tertarik untuk melakukan penelitian dengan mengangkat judul "Peranan Orang Tua Dalam Masa Perkembangan Pubertas Anak di SMP Negeri 4 Kota Bima Tahun Pelajaran 2018-2019".

Mengacu kepada uraian latar belakang dan rumusan masalah di atas, maka tujuan penelitian ini adalah ingin mengetahui peranan orang tua dalam masa perkembangan pubertas anak di SMP Negeri 4 Kota Bima Tahun Pelajaran 20182019.

\section{KAJIAN PUSTAKA}

\section{Pengertian Orang Tua}

Menurut kamus besar bahasa Indonesia, orang tua adalah terdiri dari ayah atau ibu (Poerwadarminta, 1996). Sedangkan pengertian lain menjelaskan bahwa pengertian keluarga dapat ditinjau dari dimensi hubungan darah dan hubungan sosial. Keluarga dalam dimensi hubungan darah dan hubungan sosial. Keluarga dalam hubungan darah merupakan suatu kesatuan yang diikat oleh hubungan darah antara satu dengan yang lainnya. Berdasarkan dimensi hubungan darah ini, keluarga dapat dibedakan menjadi keluarga besar dan keluarga inti. Keluarga ini 
adalah keluarga primer yang paling penting dalam masyarakat. Sedangkan dalam dimensi hubungan sosial, keluarga merupakan suatu kesatuan yang diikat oleh adanya saling berhubungan atau interaksi dan saling mempengaruhi antara satu dengan lainnya, walaupun di antara mereka tidak terdapat hubungan darah (Syaiful Bahri, 2004).

\section{Tipe Kepemimpinan Orang Tua dalam Keluarga}

a. Tipe Kepemimpinan Otoriter

Kepemimpinan otoriter ditandai dengan orang tua yang mengambil semua peran dan kekuasaan dalam kehidupan keluarga. Anak tidak diberi hak untuk mengemukakan pendapat. Anak dianggap sebagai anak kecil terus menerus. Anak tidak pernah mendapat perhatian yang banyak. Sebagai akaibat dari orang tua yang otoriter berpengaruh kepada sifat kepribadian anak, misalnya anak kurang berinisiatif, gugup, ragu-ragu, membangkang, penakut. Keseluruhan sifat kepribadian ini kelak akan merugikan perkembangan anak selanjutnya.

b. Tipe Kepemimpinan Liberal

Kepemimpinan ini mempunyai ciri di mana orang tua kurang tegas dalam memimpin anak. Anak akan menentukan sendiri apa yang diinginkannya, karena orang tua memberikan kebebasan kepada anaknya. Kepemimpinan yang demikian ini menunjukkan bahwa orang tua memegang fungsi kepemimpinan yang berwibawa. Suasana keluarga cenderung bebas, karena tidak ada norma yang harus dianut. Akibat dari pola kepemimpinan ini, anak tidak mengenal tata tertib dan kedisiplinan, anak cenderung agresif, labil, dan sering gagal karena tidak biasa berperilaku yang terbimbing.

c. Tipe Kepemimpinan Demokratis

Kepemimpinan orang tua yang demokratis disesuaikan dengan taraf perkembangan anak, cita-cita anak, minat, kemampuan yang ada pada anak. Anak ditempatkan pada posisi yang semestinya. Orang tua memberikan pertimbangan dan pendapat kepada anak, tidak hanya memaksakan pendapat dan kehendaknya sendiri. Orang tua memimpin dengan kewibawaan yang diakui, sehingga anak memberikan penghargaan kepada oranag tua di samping mengahargai juga dirinya sendiri. Pengaruh sifat kepemimpinan demokrasi kepada anak bersifat positif, antara lain anak aktif, kreatif serta berinisiatif dalam hidupnya. Anak akan percaya diri, bertanggung jawab, stabil, dan mudah menyesuaikan diri dalam kehidupannya.

\section{Fungsi Keluarga}

Menurut Syaiful Bahri (2004) mengemukakan bahwa hidup keluarga sebagai sepasang suami-isteri tidak bisa dilakukan serampangan. Namun nyatanya dalam kasuistik tertentu masih ada orang tua yang mengawinkan anaknya dalam keadaan usia dini. Misalnya yang terjadi dalam masyarakat tradisional, padahal anaknya belum siap lahir dan batin. Penyaluran nafsu seksual secara sah menurut ajaran agama melalui perkawinan bukanlah tujuan yang utama, karena tujuan lain yang lebih mulia yang ingin dicapai, yaitu ingin membentuk keluarga sejahtera lahir dan batin.dalam rangka membangun keluarga yang berkualitas tidak terlepas dari usaha anggota keluarga untuk mengembangkan keluarga yang berkualitas yang diarahkan pada terwujudnya kualitas keluarga yang bercirikan kemandirian keluarga dan ketahanan keluarga. Sedangkan penyelenggaraan pengembangan keluarga yang keluarga yang berkualitas ditujukan agar keluarga dapat memenuhi kebutuhan spiritual dan material, sehingga dapat menjalankan fungsi keluarga secara optimal. Sedangkan fungsi keluarga itu sendiri berkaitan langsung dengan aspek-aspek keagamaan, budaya, cinta kasih, melindungi, reproduksi, sosialisasi dan pendidikan, ekonomi dan pembinaan lingkungan. 
Keluarga adalah ladang terbaik dalam penyemaian nilai-nilai agama. Orang tua memiliki peranan yang strategis dalam mentradisikan ritual keagamaan sehingga nilai-nilai agama dapat ditanamkan ke dalam jiwa anak. Kebiasaan orang tua dalam melaksanakan ibadah. Disini nilai-nilai agama dapat bersemi dengan subur didalam jiwa anak menjadikannya insan-insan yang penuh iman dan taqwa kepada Allah SWT ( Sri Rumini, 2004)

Dari beberapa pendapat di atas, dapat disimpulkan bahwa fungsi keluarga dalam menciptakan suasana keharmonisan dan terciptanya suasana iklim keluarga yang sehat adalah ditentukan oleh kematangan orang tua dalam melaksanakan haka dan tanggung jawabnya dalam keluarga. Rumah tangga yang baik adalah yang memiliki suasana keakrabatan, menjadi tempat bersemainya jiwa-jiwa yang tenang dan tumbuhnya rasa bertangung jawab. Fungsi keluarga akan berjalan dengan baik jika diantara anggota keluarga memahami tugas dan tanggung jawabnya dengan benar, diiringi oleh sikap keterbukaan dan saling memahami antara satu yang lain, karena pada dasarnya kita berbeda dalam segala hal baik pikiran, perilaku, tabiat dan potensi yang dimiliki.

\section{Hubungan Orang Tua dan Anak dalam Keluarga}

Menurut Syaiful Bahri (2004) mengemukakan bahwa orang tua dan anak adalah satu ikatan dalam jiwa. Dalam keterpisahan raga, jiwa mereka bersatu dalam ikatan keabadian. Tak seorangpun dapat mencerai-beraikannya. Ikatan itu dalam bentuk hubungan emosional antara anak dan orang tua yang tercermin dalam perilaku. Setiap orang tua yang memiliki anak selalu ingin memelihara, membesarkan, dan mendidiknya. Seorang ibu yang melahirkan anak tanpa ayah pun memiliki naluri untuk memelihara, membesarkan dan mendidiknya, meski terkadang harus menanggung beban malu yang berkepanjangan. Sebab kehormatan keluarga salah satunya juga ditentukan oleh bagaimana sikap dan perilaku anak dalam menjaga nama baik keluarga. Lewat sifat dan perilaku anak nama baik keluarga dipertaruhkan.

Orang tua dan anak dalam suatu keluarga memiliki kedudukan yang berbeda. Dalam pandangan orang tua, anak adalah buah hati dan tumpuan di masa depan yang harus dipelihara dan dididik. Memeliharanya dari segala marabahaya dan mendidiknya agar menjadi anak-anak yang cerdas dan ini adalah sifat fitrah orang tua. Pada pasangan orang tua moderen yang telah mendirikan keluarga itu tidak selalu tampil dalam fungsi dan peranannya sebagai suami-isteri. Dalam hubungannya dengan anak-anaknya, keduanya tampil sebagai orang tua yang mempunyai fungsi dan peranan serta tugas dan tanggung jawabnya sebagai pendidik sehingga melahirkan pola komunikasi khusus pula diantara mereka sendiri maupun didalam hubungan dengan putra-puterinya.

\section{Perkembangan Masa Pubertas (Remaja)}

Menurut Kamus besar bahasa Indonesia (1996) Pubertas diartikan sebagai masa akil balig atau masa remaja. Sedangkan menurut Munandir (2005) pubertas adalah masa remaja, yang ditandai dengan tercapainya kematangan organ-organ kelamin. Kemudian menurut WHO (World Health Organization) pubertas adalah awal masa remaja. Pada masa pubertas terjadi perubahan badaniah yang menandai adanya kemampuan untuk melanjutkan keturunan (reproduksi) atau masa kematangan seksual (Rachmi Untoro, 1999)

Berdasarkan ketiga pendapat di atas, maka yang menjadi pengertian pubertas adalah kelompok individu yang telah masuk usia remaja yaitu pada rentangan 12-17/18 tahun yang telah ditandai adanya perubahan-perubahan fisik 
dan kematangan pada mental. Perubahan-perubahan ini jika pada laki-laki yaitu tumbuhnya bulu-bulu halus pada alat kelamin, adanya kumis dan janggut serta suaranya yang agak besar. Sedangkan pada wanita ditandai dengan tumbuhnya bulu-bulu halus pada alat kelamin, bertambah besarnya buah dada dan melebarnya pinggang serta mulai bersolek lama-lama didepan cermin.

\section{Ciri-Ciri Penting Periode Pubertas.}

Mapiare Andi (1984) mengemukakan beberapa ciri penting dari periode pubertas, adapaun ciri-ciri yang dimasud adalah sebagai berikut :

a. Pubertas merupakan periode transisi, yaitu berada dalam peralihan antara masa kanak-kanak dengan masa remaja dan tumpang tindih sebab beberapa ciri psikologis-psikologis kanak-kanak masih dimilikinya, sementara beberapa ciri remaja dimilikinya pula.

b. Pubertas merupakan periode yang sangat singkat karena dialami oleh individu hanya dalam waktu 2 sampai 4 tahun lamanya.

c. Pubertas merupakan periode terjadinya perubahan yang sangat cepat dalam hal bentuk tubuh, sikap dan sifat terhadap teman sebaya dan lawan jenis.

d. Pubertas diistilahkan dengan "fase negatip". Diistilahkan sebagai "fase" sebab waktunya demikian singkat dalam kurun waktu garis kehidupan. Disebut "negatif" karena terdapat sikap dan sifat-sifat negatif yang belum terlihat dalam masa kanak-kanak.

e. Pubertas merupakan periode munculnya secara berbeda-beda antara individu satu dengan individu lainnya. Ada individu yang cepat menunjukkan "gejala puber" dan ada yang lambat. Tetapi jarang individu yang terlalu cepat hingga sebelum usia 11 tahun dan jarang pula yang terlalu lambat memasuki masa pubertas hingga melampui usia 14 tahun.

\section{Tugas- Tugas Perkembangan Remaja dan Pelaksanaannya}

Agus Sujanto (1980) membagi tugas-tugas perkembangan remaja dan pelaksanaannya adalah sebagai berikut :

Tugas perkembangan remaja pada umumnya adalah sebagai berikut : (a) menerima keadaan psikisnya dan menerima peranannya sebagai pria atau wanita, (b) Menjalin hubungan-hubungan baru dengan teman-teman sebaya baik sesama jenis maupun lain jenis kelamin, (c) Memperoleh kebebasan secara emosional dari orang tuanya dan orang-orang dewasa lain, (d) Memperoleh kepastian dalam hal kebebasan pengaturan ekonomis, (e) Memilih dan mempersiapkan diri ke arah suatu pekerjaan atau jabatan, (f) Mengembangkan keterampilan-keterampilan dan konsep-konsep intelektual yang diperlukan dalam hidup sebagai warga negara yang terpuji, (g) Menginginkan dan dapat berperilaku yang diperbolehkan oleh masyarakat, (h) Mempersiapkan diri untuk pernikahan dan hidup berkeluarga, dan (i) Menyusun nilai-nilai kata hati yang sesuai dengan gambaran dunia, yang diperoleh dari ilmu pengetahuan yang memadai.

Tugas-Tugas perkembangan masa pubertas. Yaitu : (a) Memiliki kemampuan mengontrol diri sendiri seperti orang dewasa, (b) Memperoleh kebebasan, (c) Bergaul dengan teman lawan jenis, dan (d) Mengembangkan keterampilanketerampilan baru.

\section{METODE PENELITIAN}

Penelitian ini dirancang untuk mendapatkan data secara lengkap tentang peranan orang tua dalam membimbing anak usia pubertas. Dalam mengumpulkan 
data, peneliti membuat beberapa instrumen penelitian yaitu angket, pedoman wawancara dan pedoman observasi. Dari data yang telah dikumpulkan, peneliti melakukan analisa data melalui perhitungan persentase. Dari hasil presentase ini akan menjadi sebuah hasil penelitian tentang gambaran peranan orang tua dalam mendidik, membimbing dan menjalankan tugas dan tanggung jawabnya secara maksimal.

Yang menjadi subjek penelitian ini adalah 20 orang tua/wali siswa yang memiliki peranan dalam perkembangan pubertas anak pada SMP Negeri 4 Kota Bima. Untuk mengetahui gambaran peranan orang tua tersebut, maka peneliti memberikan angket kepada seluruh siswa yang merupakan anak dari orang tua siswa dalam penelitian. Gambaran jawaban dari siswa adalah bukti perlakuan atau pola asuh yang diberikan oleh orang tua mereka pada masa perkembangan pubertas siswa.

Untuk menemukan sejauh mana peranan orang tua dalam masa pubertas anak pada Sekolah Menengah Pertama (SMP) Negeri 4 Kota Bima, maka teknik analisis data yang di gunakan adalah analisis statistik dengan menggunakan rumus presentase. Adapun rumusnya adalah sebagai berikut:

$\mathrm{P}=\frac{M}{S M I} \times 100 \%$

Dimana:

$$
\begin{array}{ll}
\mathrm{M} & =\text { Mean rata-rata } \\
\mathrm{X} & =\text { Jumlah skor yang diperoleh } \\
\mathrm{N} & =\text { Jumlah item pertanyaan } \\
\mathrm{P} & =\text { Presentase } \\
\mathrm{SMI} & =\text { Skor Maksimal Ideal }
\end{array}
$$

\section{HASIL PENELITIAN DAN PEMBAHASAN}

\section{Hasil Penelitian}

1. Menghitung Prosentase Data hasil angket

Persentase tanggung jawab dalam perkembangan psikis

$$
\begin{aligned}
M & =\frac{1463}{40}=36,57 \\
P & =\frac{36,575}{42} \times 100 \% \\
& =87,08 \%
\end{aligned}
$$

Persentase kemampuan mendidik dan membimbing anak pubertas

$$
\begin{aligned}
\mathrm{M} & =\frac{711}{40}=17.77 \\
\mathrm{P} & =\frac{17.77}{21} \times 100 \% \\
& =84.64 \%
\end{aligned}
$$

Persentase tanggung jawab orang tua dalam pengembangan psikis dan fisik

$$
\begin{aligned}
\mathrm{M} & =\frac{961}{40}=24.025 \\
\mathrm{P} & =\frac{24.025}{27} \times 100 \% \\
& =88.98 \%
\end{aligned}
$$




\section{Menarik Kesimpulan}

Dalam menarik kesimpulan tentang peranan orang tua dalam masa perkembangan pubertas anak pada SMP Negeri 4 kota Bima tahun Pelajaran 2006/2007 dengan menggunakan Penilaian Acuan Patokan (PAP) tersebut sebagai berikut :

$$
\begin{aligned}
90 \%-100 \% & : \text { Baik Sekali } \\
80 \%-89 \% & : \text { Baik } \\
65 \%-64 \% & : \text { Sedang } \\
55 \%-64 \% & : \text { Kurang } \\
<54 \% & \text { : Sangat Kurang }
\end{aligned}
$$

\section{Data Hasil Wawancara dengan Orang Tua}

Berdasarkan hasil pengumpulan data melalui teknik wawancara, peneliti mendapatkan gambaran dari orang tua-orang tua siswa. Pengumpulan data yang dilakukan dengan teknik wawancara ini adlah bertujuan untuk menguatkan hasil penyebaran angket yang telah ditujukan kepada siswa-siswa dengan sejumlah pernyataan yang menanyakan tentang seberapa jauh yang dilakukan oleh orang tua mereka terhadap masa perkembangan pada usia pubertas ini.

Dari hasil wawancara dengan orang tua yang dilakukan, maka sebagian besar orang tua telah mampu melaksanakan tugas dan tanggung jawabnya dalam hal mendidik anak, memberikan kasih sayang, melatih dan membiasakan untuk beribadah, menyediakan fasilitas belajar anak dengan memadai. Hal ini didukung oleh pengamatan langsung peneliti ketika mereka memberikan perlakuan kepada anak-anaknya. Akan tetapi terlepas dari keberhasilan orang tua dalam memikul tanggung jawabnya, ada beberapa hal yang menjadi kendala para orang tua dalam membimbing dan mendidik adak-anak mereka pada usia pubertas, yaitu kesulitan orang tua untuk mengatasi permasalahan anak, karena mereka beranggapan bahwa kasus-kasus yang dialami oleh anak-anak saat ini berbeda dengan yang dialami oleh mereka ketika seusia pubertas, kurang memahami apa yang harus dilakukan dan dipenuhi tentang tugas-tugas perkembangan siswa. Menurut orang tua siswa, bahwa apa yang dilakukan ketika memberikan pendidikan dan bimbingan pada anak mereka itu dilakukan secara otodidak dan buah dari pengalaman yang mereka alami yang terkadang tidak efektif karena ada tingkat perbedaan pemahaman antara orang tua dan anak sangat tinggi.

\section{Data Hasil Wawancara dengan Guru}

Dari hasil wawancara dengan guru tentang pendapat mereka yang berkaitan dengan upaya mendidik, mengajar dan membimbing terhadap siswa-siswa pada usia pubertas, tergambar dengan jelas bahwa pada umumnya mereka telah mampu melakukan upaya-upaya dalam memenuhi tugas-tugas perkembangan anak pada usia pubertas. Hal-hal yang telah dilakukan adalah pemberian materi pembelajaran yang sesuai dengan tugas perkembangan mereka dalam mengatasi kemelut dalam hal psikis dan fisik, antara lain : membantu siswa dalam memecahkan persoalan belajar, membina hubungan sosial siswa dengan sesama teman-temannya, guru dan lingkungan masyarakat secara luas, menanamkan nilainilai etika dan tatakrama serta penekananan terhadap menjalankan perintah Tuhan secara menyeluruh.

\section{Pembahasan}

Pengaruh pola asuh atau perlakuan dari orang tua pada masa perkembangan pubertas anak dapat mempengaruhi pembentukan kepribadian anak usia remaja. 
Hal ini dikarenakan bahwa usia pubertas adalah merupakan usia yang rentan dengan permasalahan dalam hal tingkah laku anak. Hal ini sesuai dengan apa yang disampaikan oleh Andi Mapiare (1982) yang mengemukakan bahwa pada masa ini adalah sebagai masa ketakstabilan perasaan dan emosi, status remaja yang sulit ditentukan dan bahkan membingungkan, apakah antara anak-anak atau dewasa. Terkait dengan hal itu, maka diperlukan ketabahan orang tua dan pendidik untuk terus mendamping anak usia pubertas dalam mengatasi setiap gejolak yang tumbuh pada perasaan dan emosi mereka (Syaiful Djamarah, 2004)

Berdasarkan hasil angket tentang peranan orang tua anak usia pubertas pada SMP Negeri 4 kota Bima berdasarkan hasil pernyataan siswa atau anak usia pubertas, sering memenuhi kebutuhan, memberi kasih sayang dan merencanakan karir anak, sehingga tanggung jawab dalam perkembangan psikis mendapat presentase $87.87 \%$ merangsang intelektual anak untuk terus belajar, menanamkan akidah tauhid sehingga kemampuan orang tua mendidik dan membimbing anak pubertas mendapat persentase $84,64 \%$ dan memberikan seperangkat nilai dan sistem etika sehingga tanggung jawab dalam perkembangan psikis mendapat persentase $88,98 \%$ hal ini oleh hasil persentase dan terletak antara $80 \%-90 \%$, sehingga disimpulkan bahwa peranan orang tua dalam masa perkembangan pubertas anak pada SMP Negeri 4 Kota Bima tahun pelajaran 2018-2019 termasuk kedalam kategori "baik".

Selanjutnya data tentang hasil observasi dan wawancara untuk mendukung data hasil sebaran angket kepada siswa untuk mengetahui peranan orang tua masing-masing ketika mereka dalam masa usia pubertas, didapatkan gambaran bahwa peranan orang tua dalam keseharian mereka di lingkungan keluarga memiliki peran yang sukup signifikan. Orang tua sudah mampu melaksanakan tugas dan tanggung jawab dalam memenuhi kebutuhan anak, memberikan kasih sayang, merencanakan karir siswa, mempersiapkan untuk ke pernikahan, mendidik anak dalam mengembangkan nilai-nilai intelektualnya dan menanamkan akidah tauhid serta membimbing dalam memberikan seperangkat nilai-nilai dan sistem etika.

Dari hasil wawancara dan observasi di atas, memberikan sebuah gambaran bahwa peranan orang tua dalam memenuhi tugas dan tanggung jawabnya kepada anak-anaknya memiliki peran yang sangat fundamental. Mereka dengan antusias mengatakan bahwa walaupun kami tidak makan, demi untuk menyekolahkan anak-anak kami, apapun kami akan rela melakukannya. Akan tetapi mereka masih membutuhkan bantuan dari guru pembimbing di sekolah lewat komite untuk terus berkordinasi dengan orang tua dalam membahas tentang permasalahan yang dialami oleh siswa-siswanya.

Sebagai rangkuman dari hasil penyebaran angket, wawancara mendalam, dan observasi terhadap orang tua, maka dapat dijelaskan bahwa hasil penelitian ini, dapat dismpulkan bahwa peranan orang tua yang selalu melaksanakan tanggung jawabnya, memberikan kasih sayang, mendidik dan membimbing dengan baik, akan sangat membantu perkembangan pubertas anak, pada akhirnya tugas perkembangan anak pada masa yang dianggap sulit ini bisa dipenuhi dengan baik dan sipa untuk menghadapi dan melaksanakan tugas-tugas perkembangkan selanjutnya. Hal ini dibutuhkan kerja sama dari oranag tua, guru dn lingkungan masyarakat luas untuk menyiapkan kondisi yang kondusif bagi perkembangan anak secara sehat. Sehingga permasalahan dapat diatasi pada akhirnya prestasi belajar anak dapat diraih semaksimal mungkin.

\section{KESIMPULAN}


Berdasarkan uraian pembahasan dan hasil analisis data yang ditemukan pada penelitian ini, untk mengetahui sejauh mana peranan orang tua dalam usia pubertas anak, maka ada beberapa hal yang menjadi kesimpulan akhir dalam penelitian ini, yaitu sebagai berikut :

1. Peranan orang tua dalam mendidik dan membimbing anak pada usia pubertas, memiliki peran yang sangat fundamental. Peran orang tua adalah 1) melaksanakan tugas dan tanggung jawab dalam memenuhi kebutuhan anak, 2) memberikan kasih sayang, 3) merencanakan karir siswa, 4) mempersiapkan untuk ke pernikahan, 5) mendidik anak dan mengembangkan nilai-nilai intelektualnya dan 6) menanamkan akidah tauhid serta membimbng dalam memberikan seperangkat nilai-nilai dan sistem etika. Tugas-tugas tersebut telah mampu dilaksanakan oleh orang tua dengan baik.

2. Berdasarkan hasil penelitian, maka didapatkan gambaran bahwa peranan orang tua dalam mendidik anak usia pubertas pada SMP Negeri 4 Kota Bima telah termasuk dalam kategori baik. Peranannya dalam memenuhi tugas dan tanggung jawabnya terhadap perkembangan fisik anak yaitu mulai merawat, mengasuh, memenuhi kebutuhan-kebutuhan gizi serta upaya merangsang pertumbuhan anak yang sehat mendapat peresentase $87,08 \%$ dan termasuk kategori baik, kemampuan dalam mendidik dan membimbing anak dengan berperan untuk menanamkan nilai-nilai agama, tata krama, sopan santun serta menyediakan dan menfasilitasi kegiatan belajar anak, mendapatkan 84,64\% dalam kategori baik. Sedangkan peran orang tua dalam mengembangkan psikis anak yaitu melatih mental, memberikan kasih sayang dan memenuhi kebutuhan spiritual anak terletak pada katogori 88,98 \%. Dari ketiga persentase perqanan orang tua tersebut berada pada kategori antara $80 \%-89$ $\%$, sehingga disimpulkan bahwa peranan orang tua dalam masa perkembangan pubertas anak pada SMP Negeri 4 Kota Bima adalah termasuk kategori "Baik".

\section{DAFTAR RUJUKAN}

Arikunto Suharsimi, 1983, Prosedur Penelitian. Suatu Pendekatan Praktek, Penerbit Rineka Cipta, Jakarta.

Bahri Syaiful, 2004. Pola Komunikasi Orang Tua dan Anak dalam keluarga. Penerbit Rineka Cipta. Jakarta

Daradjat Zakiyah, 1979, Kesehatan Mental, Gunung Agung. Jakarta

Mapiare Andi,1982. Psikologi Remaja. Usaha Nasional Surabaya.

Mapiare Andi, 1984. Pengantar Bimbingan dan Konseling di Sekolah. Usaha Nasional Surabaya.

Monks. F.J. Knoers, 1982. Psikologi Perkembangan. Pengantar dalam Berbagai Bagiannya. Gadjah Mada University Press. Yogyakarta.

Poerwadarminta, WJS. Kamus Umum Bahasa Indonesia. Balai Pustaka. Jakarta.

Rumini dan Sundari, 2004. Perkembangan Anak dan Remaja. Penerbit Rineka Cipta. Jakarta.

Riyanto Yatim, 2001. Metodologi Penelitian Pendidikan. Usaha Nasional, Surabaya.

Save M.Dagun, 2002. Psikologi Keluarga. PT. Rineka Cipta. Jakarta.

Syaiful Bahri, 2004. Pola Kumunikasi Orang Tua dan Anak dalam Keluarga (sebuah Perspektif Islam).PT. Rineka Cipta Jakarta. 
Sudjana Nana,1987. Tuntunan Penyusunan Karya Ilmiah (Makalah, skripsi, tesis dan Disertasi) Penerbit Sinar baru. Bandung.

Sobur Alex, 1991. Komunikasi Orang Tua dan Anak. Angkasa Bandung.

Siahaan, Henry, 1991. Peranan Ibu Bapak Mendidik Anak, Angkasa Bandung.

Sutari IB.(1984) Pengantar Ilmu Pendidikan. FIP IKIP.Yogyakarta.

Sujanto Agus, 1980. Psikologi Perkembangan. Aksara Baru Jakarta.

Untoro Rachmi, 1999. Kesehatran Reproduksi Remaja (KRR). Penerbit Departemen Kesehatan Repoblik Indonesia dan WHO. Jakarta.

Winarno, Surachman. 1994. Metodologi Penelitian dan Teknik Metodologi Pengajaran. Tarsito Bandung. 